\title{
Ethical Consumption as the Basis for Counteracting Food Waste
}

*

**
Narodowy Instytut Kultury i Dziedzictwa Wsi;

Państwowa Wyższa Szkoła Wschodnioeuropejska w Przemyślu

e-mail: mikolaj.niedek@nikidw.edu.pl

\section{Keywords:}

sustainable consumption pattern, sustainable lifestyle, food waste, food ethics, ethics of consumption, ethical consumption, frugalism

\section{Abstract}

The objective of the article is to present the concept of practical consumer ethics, which may constitute the axiological basis of sustainable consumption and such an attitude of the consumer that will prevent the negative impact of food consumption on the natural and social environment and will counteract the food waste. The authors consider ethical consumption against the background of the normative pattern of sustainable consumption, which is the practical operationalisation of the concept of sustainable development. This pattern implies, on the one hand, consumer ethics and, on the other hand, an environmentally and socially responsible lifestyle. Against this background, the authors postulate the concept of frugalism as a practical ethics of consumption, based on aretological assumptions and the values of Henryk Skolimowski's ecological ethics. Frugalism, in its normative assumptions, contributes to deconsumption by changing the system of values, attitudes and preferences of a consumer, who voluntarily decides to limit the amount of purchased products, preferring those that are recycled and more sustainable. The authors present comparative statements of the features of the consumerist and frugalistic attitudes.

(c) IOŚ-PIB

\section{INTRODUCTION}

The research areas of the article are the determinants of sustainable consumption that are related to the value systems that guide the consumer in his behaviour on the market of food products and in his handling of these products in the household. The shaping of sustainable consumption patterns is an operationalisation of the concept of sustainable development. The shaping of sustainable consumption attitudes and behaviours that favour the implementation of ecologically and socially sustainable consumption patterns can be an important countermeasure in the prevention of food waste in households. The aim of the article is therefore to identify such ethical values system, that can constitute a permanent basis for the practice of sustainable consumption and a lifestyle that opposes consumerism and aims to reduce consumption and food waste at the end of the agri-food chain. The article begins with an introduction to the issues of sustainable production and consumption patterns, and then moves on to the topics related to food ethics and consumer ethics.

\section{RESEARCH MATERIALS AND METHODS}

The research material falls within the scope of economic and social sciences as well as philosophy and ethics in the field of food ethics, ethics of consumption and environmental ethics. The research material included in the article was selected from Polish- and English-language literature and is subjected to comparative analysis, synthesis and systematisation. The views presented in the article are supported by relevant literature and illustrated with quotations. The assumption adopted in the article is a significant impact of the adopted ethical values on consumer attitudes and choices.

\section{SUSTAINABLE CONSUMPTION AND LIFESTYLE}

Among the Millennium Sustainable Development Goals adopted by the United Nations in 2015 as part of the 2030 Agenda for Sustainable Development, the goal 12 relates 
directly to sustainable consumption and production. In support of this goal, the UN emphasises that world consumption and production - the driving force of the global economy - are based on the use of the environment and resources in a way that has a destructive effect on the planet. They cause increasing environmental pollution, resource depletion, degradation of ecosystems and loss of biodiversity; and in the long term they cause the erosion of the material basis for the functioning of the economy and the global living system [UN 2021]. The issue of sustainable consumption and production has been shaped since the beginning of the 1990s, starting with the Agenda 21 adopted in 1992 at the UN conference in Rio de Janeiro; it emphasised the role of a cleaner, environmentallyfriendly production, which should provide consumers with more sustainable products. Since the next UN 'Earth Summit"', which took the place in Johannesburg in 2002, the need for changes in individual and public consumption patterns and consumer education have been emphasised. In Poland, in 2003, the government adopted the 'Strategy for changing consumption and production patterns to favour the implementation of the principles of sustainable development' [Ministerstwo Gospodarki 2003]. In 2008, the European Commission published the Communication on the Sustainable Consumption and Production [COM 2008], and the issue of sustainable consumption was then taken up and developed in a number of documents adopted by international organisations. Although production and consumption as the basic processes of economic activity occur jointly in socioeconomic practice and they imply each other, the subject of this article is basically consumption, understood as the process of purchasing and using (consuming) goods by consumers, determined by a socially and culturally defined consumption pattern and a system of values standing at its base [Janoś-Kresło 2006]. According to the authors of this article, sustainable consumption should be treated as an operationalisation of the concept of sustainable development, to which specific indicators can be assigned to enable its monitoring [Jaros 2014]. An example of an indicator monitoring the level of (un)sustainability of consumption is the scale of food waste. In all nexus of the food chain it amounts to 4.8 million tonnes per year in Poland [ $Ł a b a$ et al. 2021]. Counteracting food waste at all stages of the agri-food chain - from production and distribution to trade and consumption in shops, gastronomic points and households - is an important element of the sustainability of the food chain [Bilska et al. 2015]. In addition to the descriptive aspect related to the acquisition of qualitative and quantitative data on consumption and food waste, there is also its normative dimension related to shaping its pattern [Niedek, Krajewski 2020]. The authors will continue to focus on this.

A balanced pattern of consumption that meets the sustainability criteria can be understood conjunctively as:

a) to consume sufficient number of goods and services to meet needs and achieve a high quality of life, without unnecessary waste of products, materials and energy; b) consumption with a preference towards ecologically and socially sustainable products; and

c) dematerialising (minimising and saving) the use of natural resources and preferring the consumption of services rather than things [Niedek 2009].

The two aspects can be distinguished in the consumption process: 1) subjective - connected with the consumer, and more broadly with the human being - his system of values, knowledge, attitudes and preferences that translate into specific decisions, choices and consumer behaviour; and 2) objective - relating to the object of consumption - goods and services, their generic, qualitative and quantitative aspects. In the subjective aspect, sustainable consumption refers to the consumption of goods and services at a level sufficient to meet basic needs and achieve an adequate quality of life; in the objective aspect, to the consumption of such goods, the production of which took place with a minimised and efficient use of resources, raw materials, materials and energy, and the consumption of which minimises the waste. Changes in the structure of the consumption processes, through the demand mechanism, affect the supply side, which is directly related to production. Consumption patterns, determining its quantitative and qualitative character, include both its subjective dimension - through a specific system of values and views adopted by the consumer - and its objective dimension, through a specific structure of preferences towards purchased products (goods and services). The opposite of sustainable consumption is unsustainable consumption, which is characterised by:

a) consuming goods to an extent which is excessive in relation to the necessary needs and on a larger scale than required by an adequate quality of life, resulting in a waste of resources, energy, food;

b) consuming unsustainable products - harmful directly or indirectly to the environment and to the health of the people producing and consuming them;

c) excessive use of resources, raw materials, water and energy in relation to the production capacity of the environment and its ability to assimilate pollution and waste.

Consumption should not be considered only as an economic activity, but as an element of a wider whole, such as the patterns that function and dominate in society: norms, values, fashions and trends. Internalised by the consumer, they create a psychological and axiological structure of consumer motivations and preferences, which translate into specific attitudes, behaviours, choices and decisions of the consumer.

According to M. Cohen, the activities and achievements to date for the implementation of sustainable consumption do not correspond to the ambitious commitments announced in the adopted political plans and international agreements; they require new, innovative approaches and changes at the organisational level, in the way communities function and in the lifestyles [Cohen 2019]. On the other hand, according to 


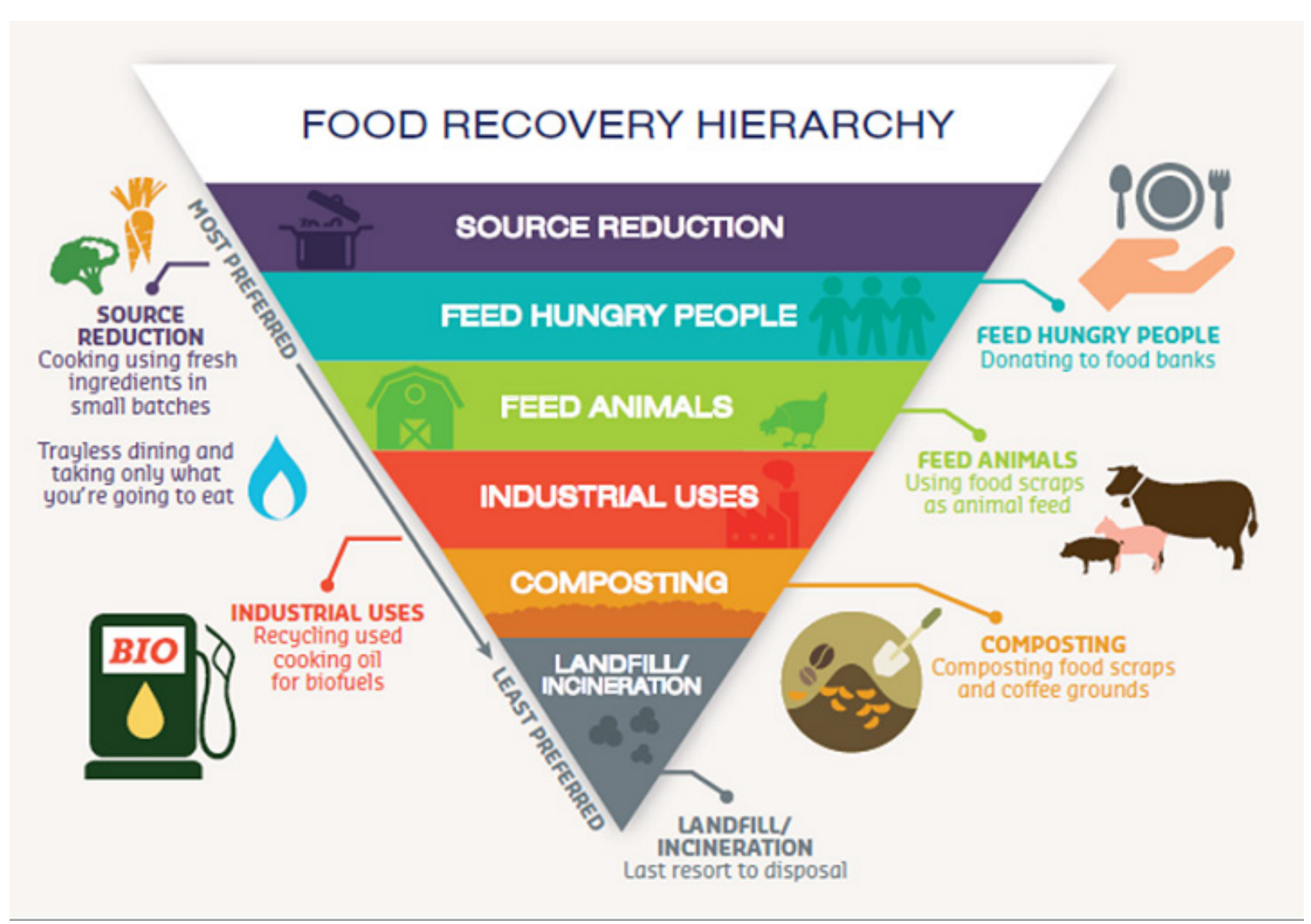

Figure 1. Food Recovery Hierarchy. Source: https://www.bioenergyconsult.com

P. Nieuwenhuis, D. Newman, and A. Touboulic, changes in the area of consumption, which is the central element of the modern market economy, require focussing on the human attitude towards the goods purchased [Nieuwenhuis 2021]. The attitude of a consumer to things and the world, in turn, is determined by the system of values he professes and the style of life he practices, which can be understood as'a system of values, interests, views and behaviours of the consumer that influence his consumption behaviour'[Antonides 2003]. In the context of sustainable consumption, the key issue is therefore the topic of sustainable lifestyle, which can in turn be regarded as the operationalisation of the concept of sustainable consumption and the practical implementation of its pattern. Thus, the lifestyle also includes non-economic dimensions: psychological, cultural, philosophical and ethical'.

\section{PRINCIPLES OF PREVENTING FOOD WASTE}

According to D. Szwajca, the adoption of the assumptions of ethical (socially responsible) consumption requires the

1 The broader social and ecological point of view on consumption is applied by the economy of sustainable development (Rogall 2010). change of the consumer value system based on hedonism and egoism (egocentrism) to a system based on such values as: social justice, respect for other people, empathy, co-responsibility for the natural environment and for the welfare of future generations [Szwajca 2018]. Erich Fromm, who defined excessive consumption (consumerism) as a state of permanent unsaturation, motivated by striving for an ever higher level of prosperity, catching up with wealthier people, impressing them and entering a given social group, has already paid attention to the cultural and psychological basis of the shaping of the consumer society; it is like trying to reach a point on the horizon [Fromm 1995]. The economic and cultural trends of key importance for the phenomenon of food wastage include overconsumption (hyperconsumption) and consumerism [Bylok 2016 a]. It is opposed by deconsumption, which consists in deliberately reducing consumption and adopting alternative, more socially and ecologically sustainable consumption patterns and lifestyles [Bylok 2016 b]. Changes in consumer attitudes are related to market, social and cultural changes, which have their counterpart in the area of ethical values that guide people as consumers [Rogala 2015]. In the face of the contemporary scale of overconsumption and the resulting losses and wastage of food, there is a normative need to limit, counter and prevent them. 
According. B. Roe, D. Qi, and K. Bender, the main ethical issue in the area of counteracting food waste is the problem of food reallocation, which involves three main issues: 1) who should sacrifice (change current behaviour)?; 2) who should benefit from it?; and 3) what methods are appropriate to induce the behaviour change needed to carry out reallocation? [Roe, Qi, Bender 2020]. These authors see the direction of possible solutions in: 1 ) food donation; 2) creating markets for imperfect-looking food (so-called 'ugly food'); and 3) educational and dutybuilding appeals to motivate food waste reduction and a better understanding of the use-by dates on food labels. These authors refer to the hierarchy of food recovery principles developed by the US Environmental Protection Agency, shown in the figure 1. It is based, similarly to the European hierarchy of waste management rules, on the $3 R$ principle: Reduce, Reuse, Recycle.

In the context of combating food waste and the generation of it, these principles can take the form of practical guidelines for consumer behaviour:

1. Avoid overbuying and accumulating food and prevent it from expiring;

2. Manage unused food products;

3. Share the food or give it to those in need.

Such attitudes are praxeological (practical) in nature, but for their durability, they should be based on deeper ethical principles (values) from which they arise.

\section{ETHICS OF FOOD AND CONSUMPTION}

Ethical reflection on food issues has been taking shape since the mid-90s of the twentieth century [Mepham 1996]. The studies systematising the subject and scope of food ethics [Sandler 2015], as well as devoted to its genesis [Zwart 2000], focus mainly on ethical issues related to food production and pay less attention to the issues of consumer values and obligations. Ethical conditions related to the production and distribution of foods are better identifiable and theoretically developed in the field of food ethics than the issues of desired consumer behaviour in relation to food handling. An example of ethical regulations in the field of food production is the Code of Food Ethics [Kodeks etyki żywnościowej 2020] adopted by the Minister of Agriculture Jan Krzysztof Ardanowski in March 2020. It concerns essentially the role of food producers, processors and distributors in shaping a socially and ecologically responsible agri-food chain. The issues of ethical obligations of the consumer are also developed on the basis of the CnSR Consumer Social Responsibility concept [Vitell 2015]. The field of ethical reflection devoted to the obligations of the consumer is the ethics of the consumer.

Sustainable consumption is also defined in the literature as responsible, balanced, ecological and ethical. The subject of ethical reflection on consumption should include a number of various practices, including: human rights (including working conditions), people's health, care for the welfare of farm animals and the natural environment, and product quality (perceived through the prism of its durability and harmlessness for the environment) [Neale 2015]. 'From the perspective of the ethics of consumption, a socially responsible consumer should be considered a responsible and socially aware person, whose activities on the market are morally justified and who must be ready to give up their consumption desires (...) The factor influencing the formation of a socially responsible consumer is pro-ecological awareness based on ethical values that stimulate greater responsibility for decisions made in the sphere of consumption. This awareness is based on the assumptions of sustainable consumption based on the moderate, economical use of natural resources and ecological responsibility towards future generations' [Bylok $2016 \mathrm{c}$. Ethical consumerism as a theoretical concept and at the same time a social movement emerged in response to the negative impact of consumption on individuals, society and the natural environment. According to this concept, 'buying is not only an economic act, but also a commitment to these and not other values, and has specific effects not only for the buyer, but for everyone in the supply and production chain. (...) Responsibility may also manifest itself in limiting buying and consumption, which is a protest against the unsustainable lifestyle or approval of the concept of sustainable development' [Lewicka-Strzałecka 2018].

The quoted professor A. Lewicka-Strzałecka questions the exclusivity of applying in the ethics of consumption both the deontological approach (ethics of norms, orders and bans) as well as the consequentialist (utilitarian) approach - consisting in the analysis and balance of benefits that a given consumer choice may have for the natural and social environment. She tends towards the ethics of virtue (character), for which the ethical paradigm was developed by Alasdair Maclntyre [Maclntyre 1996]. In this approach, the general moral condition of the subject, his character traits, motives and intentions, shaped essentially by virtues, understood as acquired and permanent dispositions to specific behaviours, are of key importance for the ethical attitude. In the context of the sustainable consumption postulate, which is to counteract the consumption of and ecological and social imbalance, the value (virtue) of moderation is of key importance as it has a stabilising (balancing) meaning. From antiquity, moderation, along with prudence, fortitude and justice, belongs to the classical and traditional values of Latin culture. It is based on the Aristotelian principle of the golden mean, balancing pejorative extremes: underflow and excess. According to Aristotle, virtue is '(...) a constant disposition to certain kinds of decisions, consisting in maintaining an average measure appropriate for us, which is determined by reason (...). It is an average measure between two errors, i.e., between excess and scarcity'[Arystoteles 2007]. The virtue of moderation seems especially relevant in the era of overconsumption dominating in modern society [Smółka 2020].

To the important virtues in this context, A. Lewicka- 
Table 1. Comparison of the characteristics of consumerist and frugalistic attitudes (Elaborated by M. Niedek).

\begin{tabular}{|c|c|}
\hline Features of the consumerist attitude & Features of a frugalistic attitude \\
\hline Overconsumption & Sustainable and moderate consumption \\
\hline Compulsive consumption & Consumption resulting from real needs \\
\hline Satisfying desires and whims & Satisfying real needs \\
\hline Waste & Recovering \\
\hline Ostentatious and snobbish consumption & Modesty \\
\hline $\begin{array}{l}\text { Consumption of cheap and perishable goods (low- } \\
\text { quality products, junk food) }\end{array}$ & $\begin{array}{c}\text { Consumption of durable and high-quality goods (in } \\
\text { particular of ecological quality) }\end{array}$ \\
\hline The predominance of consumption of material goods & $\begin{array}{l}\text { Consumption of intangible goods (knowledge, art, } \\
\text { beauty, services) - focussing on personal, spiritual and } \\
\text { interpersonal development }\end{array}$ \\
\hline $\begin{array}{l}\text { Self-centred consumption, without awareness of } \\
\text { ecological and social effects and costs }\end{array}$ & $\begin{array}{c}\text { Consumption aware of the social and environmental } \\
\text { impact }\end{array}$ \\
\hline $\begin{array}{l}\text { Hedonistic consumption (aimed at instant gratification } \\
\text { here and now) }\end{array}$ & $\begin{array}{l}\text { Consumption aware of the pre-consumption stage (origin, } \\
\text { way of producing products) and post-consumption stage } \\
\text { (way of managing post-consumer waste) }\end{array}$ \\
\hline
\end{tabular}

Strzałecka also adds: prudence, activity and environmental responsibility. According to her, the prudence virtue of the consumer is the ability to satisfy one's own needs and achieve goals with the help of properly selected consumer goods. A prudent consumer is able to maintain his subjectivity, being aware of the role and functions of consumption in human life and the consumer's position on the market, as well as knowledge about the ways of influencing people through marketing and advertising. The opposite of prudence is recklessness making people passive objects, reduced to simple emotions that can be easily controlled; while the virtue of activity is the disposition to act, making consumption an instrument to achieve higher goals. Activity may be manifested, inter alia, in gaining knowledge about the purchased goods and services beyond information about immediate benefits, in readiness to broaden the awareness of consumer rights and the ability to use them; in turn, the consumer's environmental responsibility includes concern for the impact of his choices on the social and natural environment. It involves the use of knowledge about the social conditions of the processes of producing and selling products in consumer decisions. Therefore, the ethics of consumption based on dispositions of character is postulated as a constructive moral proposition based on aretological values (Greek: arete - virtue), formulated in response to the criticism of consumerism: corporations, forced in various ways to 'buy things that they do not need with money they do not have' [Lewicka-Strzałecka 2018]. In the ethics of consumption, moral subjectivity and autonomy in making consumer decisions are ascribed to the consumer. According to A. Lewicka-Strzałecka, the aretological concept of consumer ethics assumes that consumption is not only a sphere serving to satisfy human needs, but is also an area of interaction between his market choices and personality shaping. Systematically made decisions regarding the purchase, use or disposal of specific goods affect not only the environment, but also change the people who make them [2018]. Since consumption is a necessary human activity and practiced by all people, consumer ethics based on character and personality traits are built into them, regulating them in a manner consistent with sustainable consumption patterns. It is universalistic and can be used by everyone, on the same basis as consumption is a type of activity common to all people.

\section{FRUGALISM}

The english word frugality reflects all the three values: economy, moderation, modesty. As a moral value, it was adopted within the eco-ethics of Henryk Skolimowski (1930-2018), the polish creator of ecological philosophy (eco-philosophy), along with such values as reverence for life, empathy, responsibility, diversity, eco-justice for all and hope. Recognising frugality as the central and general determinant of the pro-ecological and ethical attitude, its dissemination and practice in everyday life can be described as frugalism. Frugality is understood by Skolimowski as follows: '... is a carrier of responsibility, a way of being responsible in a world where there are many limitations and interdependencies. To understand the rights of others to life is to limit your own needs. The message of one of the Franciscan houses is "Everything we have above our needs is stolen from those who have less than they need." (...) Frugality is the optimal way of being among other beings. The real awareness of moderation and its proper realisation comes from the conviction that the most valuable things are not obtained for money: friendship, love, inner joy, freedom of inner development. (...) On an even higher level, frugality is a state of grace without waste. (...) it is not a prohibition or a negative commandment (be moderate 
and live in poverty), but a positive command: be moderate and radiate health and grace. (...) Aristotle was aware of the beauty of a moderate attitude when he wrote that the rich are not only those who have a lot, but also those who need little. (...) You cannot be truly reverent towards life if you are not moderate in today's world, where the state of balance is so delicate and so easy to breach' [Skolimowski 1993]. In the context of the above-characterised balanced pattern of consumption, sustainable lifestyle and ethics of consumption, frugalism can therefore be defined as a permanent ethical disposition of the character of a human being aimed at satisfying consumption needs in a moderate, economical and modest manner, opposing the consumption of excess and wastage, and aware of wider social and environmental consequences of the acts of consumption. The condition for this attitude is therefore the recognition of real and genuine consumer needs, having ecological awareness and knowledge, and directing life energy towards more spiritual than material development (deconsumption and dematerialisation of consumption). Table 1 presents a comparative comparison of the features of the consumerist (overconsumption) attitude with the frugalistic one.

The values on which the frugalism - as the consumer ethical paradigm - is based on the classical virtues cultivated since antiquity. Attitudes of moderation, thrift and modesty were practiced before the advent of the consumer society, often under the influence of economic circumstances related to scarcity and poverty. Today, they can be practiced consciously and voluntarily, proving that the values of ethical and moral limitations are accepted as a free and conscious choice of man on the way to fulfillment and self-realisation that cannot be reduced to pure consumption. The other systems of ethical consumption and practice of sustainable lifestyles, which also contribute to counteracting food waste, can be included in the social movements and trends, such as Slow Life, Voluntary Simplicity, minimalism and freeganism [Zrałek 2015].

\section{CONCLUSIONS}

The issue of environmental impact from excessive consumption has been developed on the basis of the concept of sustainable development since the 1990s. The main problems in this area are consumerism, which in the case of food means the related waste of food products and the raw materials, energy, water and labor contained in these products. Shaping sustainable consumption patterns is considered to be a way of operationalising the concept of sustainable development and its implementation into socioeconomic and market practice. Socially and ecologically responsible consumption should be ethically based and expressed through a sustainable lifestyle. Reflections conducted in the field of food ethics, ethics of consumption and environmental ethics try to develop such systems of values and methods of conduct that will create a permanent basis and guidelines for such consumer behaviour that will be environmentally friendly and solidary with other social groups. One of the key values that can help prevent food waste is frugality: of being moderate, modest and thrifty. Such attitudes, if they become permanent traits of the consumer's character and behaviour can, from a normative point of view, prevent hyperconsumption and its negative social and environmental impacts. The ethical consumer attitude practiced as a lifestyle can be described as frugalism. Motives for such practical ethics can be found in the ecoethics of Henryk Skolimowski. Practical tips on ethical handling of unused food are also provided by the hierarchy of food recovering, which orders to avoid buying excessive amounts of food in the first place, and then recover it by giving it back to those in need.

\section{REFERENCES AND LEGAL ACTS}

ANTONIDES G., 2003. Zachowanie konsumenta. w: van Raaij W.F., Podręcznik akademicki, WN PWN, Warszawa.

ARYSTOTELES. 2007. Etyka nikomachejska, tłum. D. Gromska, PWN, Warszawa.

BILSKA B., WRZOSEK M., KRAJEWSKI K., KOŁOŻYNKRAJEWSKA D., 2015. Zrównoważony rozwój sektora żywnościowego a ograniczenie strat $i$ marnotrawstwa żywności. Journal of Agribusiness and Rural Development, nr 2(36), s.171-179

BYLOK F., 2016 (a). Konsumpcja, konsument i społeczeństwo konsumpcyjne we współczesnym świecie. Katowice, 2016.

BYLOK F., 2016 (b). Alternatywne formy konsumpcji wobec konsumpcjonizmu, Politechnika Częstochowska, HANDEL WEWNĘTRZNY 2(361), str. 63-77.
BYLOK F., 2016 (c). Konsumpcja hedonistyczna a konsumpcja etyczna, czy potrzebna jest społecznie odpowiedzialna konsumpcja?. Studia i Prace WNEiZ, nr 44/2 2016, Szczecin.

COHEN M., 2019. Introduction to the Special Issue: Innovative Perspectives on Systems of Sustainable Consumption and Production. Sustainability: Science, Practice and Policy 15 (1).

FROMM E., 1995. Mieć czy Być. Rebis.

JANOŚ-KRESŁO M., 2006. Konsument $i$ konsumpcja we współczesnej gospodarce, w: Mróz B. (red. nauk.) SGH, Warszawa.

JAROS B., 2014. Pomiar zrównoważonej konsumpcji. OPTIMUM. STUDIA EKONOMICZNE NR 3 (69). 
KODEKS ETYKI ŻYWNOŚCIOWEJ, 2020. pod honorowym patronatem Prezydenta RP Andrzeja Dudy. https://www. gov.pl/web/rolnictwo/kodeks-etyki-zywnosciowej

Communication from the Commission to the European Parliament, the Council, the European Economic and Social Committee and the Committee of the Regions on the Sustainable Consumption and Production and Sustainable Industrial Policy Action Plan COM/2008/0397 final. Brussels. 16.07.2008.

$Ł A B A \quad$ S., BILSKA B., TOMASZEWSKA M., ŁABA R., SZCZEPAŃSKI K., TUL-KRZYSZCZUK A., KOSICKA-GĘBSKA M., KOŁOŻYN-KRAJEWSKA D., 2021. Próba oszacowania strat i marnotrawstwa żywności w Polsce. Przemysł Spożywczy, 2021, 74.

LEWICKA-STRZAŁECKA A., 2018. Etyka konsumenta w perspektywie aretologicznej, Diametros 56.

MACINTYRE A., 1996. Dziedzictwo cnoty. Studium z teorii moralności, tłum. A. Chmielewski, PWN, Warszawa.

MEPHAM B., 1996. Food ethics, Routledge.

NEALE A., 2015. Zrównoważona Konsumpcja. Źródła koncepcji i jej zastosowanie. Prace Geograficzne, Zeszyt 141, Instytut Geografii i Gospodarki Przestrzennej UJ, Kraków.

NIEDEK M., 2009. Determinanty rozwoju partnerstwa międzysektorowego na rzecz równoważenia wzorców konsumpcji i produkcji. Rozprawa doktorska (praca niepublikowana) pod kier. prof. dr hab. Dariusza Kiełczewskiego, Wydz. Ekonomiczny Uniwersytetu w Białymstoku.

NIEDEK M., KRAJEWSKI K., 2020. Problematyka marnowania żywości w Polsce, a kształtowanie wzorca zrównoważonej konsumpcji, Studia Ecologiae et Bioethicae, UKSW, t. 19, nr 2: 17-28.

NIEUWENHUIS P., 2021. Sustainable Consumption, Production and Suply Chain Management. w: Newman D. i in. Advancing Sustainable Management Systems.

ROE B. E., QI D., BENDER K. E., 2020. Some issues in the ethics of food waste, Physiology \& Behavior Volume 219, 15.

ROGALA A., 2015. Współczesna konsumpcja żywności w pułapce paradoksu postmodernistycznego świata, Journal of Agribusiness and Rural Development, 3(37), 513-520.
ROGALL H., 2010. Ekonomia zrównoważonego rozwoju, tłum. J. Gilewicz.

Ministerstwo Gospodarki RP. 2003. Strategia zmian wzorców konsumpcji i produkcji na sprzyjające realizacji zasad trwałego i zrównoważonego rozwoju.

SANDLER R. L., 2015. Food Ethics. The basics, New York.

SKOLIMOWSKI H., 1993. Filozofia żyjąca. Eko-filozofia jako drzewo życia, tłum. J. Wojciechowski, Warszawa.

SMÓŁKA L., 2020. Cnota umiaru w kulturze nadmiaru. Horyzonty Wychowania, 19(52).

SZWAJCA D., 2018. Consumer Social Responsibility (CnSR) and CSR in the Context of Sustainable Development [in]: Business and non-profit organizations facing increased competition and growing customers'demands, Vol. 17, str. 468.

VITELL S. J., 2015. A Case for Consumer Social Responsibility (CnSR): Including a Selected Review of Consumer Ethics/ Social Responsibility Research, Journal of Business Ethics volume 130.

ZRAŁEK J., 2015. Voluntary Simplicity - zrównoważony styl życia współczesnych konsumentów. Studia Ekonomiczne. Zeszyty Naukowe Uniwersytetu Ekonomicznego w Katowicach $\mathrm{Nr} 231$.

ZWART H., 2000. A Short History of Food Ethics, Journal of Agricultural and Environmental Ethics volume 12, pages 113-126.

\section{STRONY INTERNETOWE}

UN. 2021, https://www.un.org/sustainabledevelopment/sustainable-consumption-production/ (dostęp 10.06.2021)

https://www.bioenergyconsult.com 